\title{
The role of connective tissue in the embryology of the
}

\section{musculoskeletal system: towards a paradigm shift [version 1; peer review: 2 approved with reservations]}

\section{Carolina Marchuk¹, Carla Stecco²}

${ }^{1}$ Program of Professional Training on Osteopathy, Universidad Abierta Interamericana - Centro de Estudio de Terapias Manuales, Buenos Aires, Argentina

2Department of Molecular Medicine, University of Padova, Padova, Italy

V1 First published: 27 Aug 2015, 4:635

https://doi.org/10.12688/f1000research.6824.1

Latest published: 27 Aug 2015, 4:635

https://doi.org/10.12688/f1000research.6824.1

\section{Abstract}

This paper presents a review of literature regarding the role of embryological connective tissue in the formation of muscles and the organization of the musculoskeletal system. The intention is to introduce a potential paradigm shift with regards to understanding peripheral coordination of movement and movement patterns. This new perspective could improve comprehension of the normal physiological function of connective tissue and, whenever it is pathological, resultant symptoms. Furthermore, this paper briefly discusses some implications of this paradigm shift in the interpretation of movement patterns, posing further questions for future research.

Keywords connective tissue, embryology , anatomy and physiology , movement patterns, fascial manipulation.

This article is included in the Fascia research collection.

\section{Open Peer Review \\ Approval Status? ? 2

version $1 \quad$ ? ? \\ 27 Aug 2015 view view \\ 1. Benjamin Feldman, National Institutes of Health, Bethesda, USA \\ 2. Simon Hughes, King's College London, London, UK \\ Any reports and responses or comments on the article can be found at the end of the article.}


Corresponding author: Carolina Marchuk (carolinamarchuk@gmail.com)

Competing interests: No competing interests were disclosed.

Grant information: The author(s) declared that no grants were involved in supporting this work.

Copyright: $\odot 2015$ Marchuk C and Stecco C. This is an open access article distributed under the terms of the Creative Commons Attribution License, which permits unrestricted use, distribution, and reproduction in any medium, provided the original work is properly cited.

How to cite this article: Marchuk $C$ and Stecco $C$. The role of connective tissue in the embryology of the musculoskeletal system: towards a paradigm shift [version 1; peer review: 2 approved with reservations] F1000Research 2015, 4:635 https://doi.org/10.12688/f1000research.6824.1

First published: 27 Aug 2015, 4:635 https://doi.org/10.12688/f1000research.6824.1 


\section{Introduction}

Before being ejected from the ovarian follicle, the ovum is covered by a double sac: theca interna and theca externa (Moore \& Persaud, 1999). Once released, the ovarian follicle is covered like every other cell — by a phospholipid bilaminar membrane, which acts as a double sac surrounding the content of the cell. During ovulation, the ovum released from the follicle is surrounded by another membrane, a lining of mucopolysaccharides' translucent gel called zona pellucida. After fertilization, the ovum divides itself an indefinite number of times within the zona pellucida. This shell of 'fundamental substance' covering the zygote constitutes the first meta-membrane of the organism. This is the first connective tissues product to fulfill this function, followed by the reticulum and collagen fibroid components. This ooze is the primordial organismic membrane as well as the original organismic environment. A little amount of cytoplasm leaves the two daughter cells in the process of the first division and it creates a thin layer of fluid which surrounds the two cells and between the cells and the zona pellucida. (Moore \& Persaud, 1999). This is the interstitial or lymphatic fluid, the principal means of exchange in the community of cells within the organism. The cells keep dividing and five days later they form a hollow sphere of cells called the blastocyst. During the following two weeks the blastocyst invaginates and undergoes gastrulation, a process in which pseudopods form in each corner of the blastocyst that join with other cells to make a whole, then a crater, and finally a tunnel, differentiating into two layers: an internal and an external one (Moore \& Persaud, 1999). Thus, three spaces are created: the inside of the internal sac, the environment of the external sac and a space in between these two. When invagination is complete, it gives rise to two double sacs: the amniotic sac and the yolk sac surrounded by three germinal disc layers consisting of Ectoderm, Mesoderm and Endoderm (Figure 1).

These layers are intertwined between the two sacs in the following way:

- The Ectoderm will form the nervous system, neural networks and skin in contact with the amniotic sac and fluid.

- The Mesoderm will form the muscles, the connective tissues (so being the precursor of the fibrous net), the blood, lymph, kidneys, part of the genital organs and the adrenal cortex glands. It is located in the middle of the ectoderm and the endoderm.

- The endoderm will form the tracts of our blood vessels, the organs of the digestive system and the glands. It is in contact with the yolk sac.

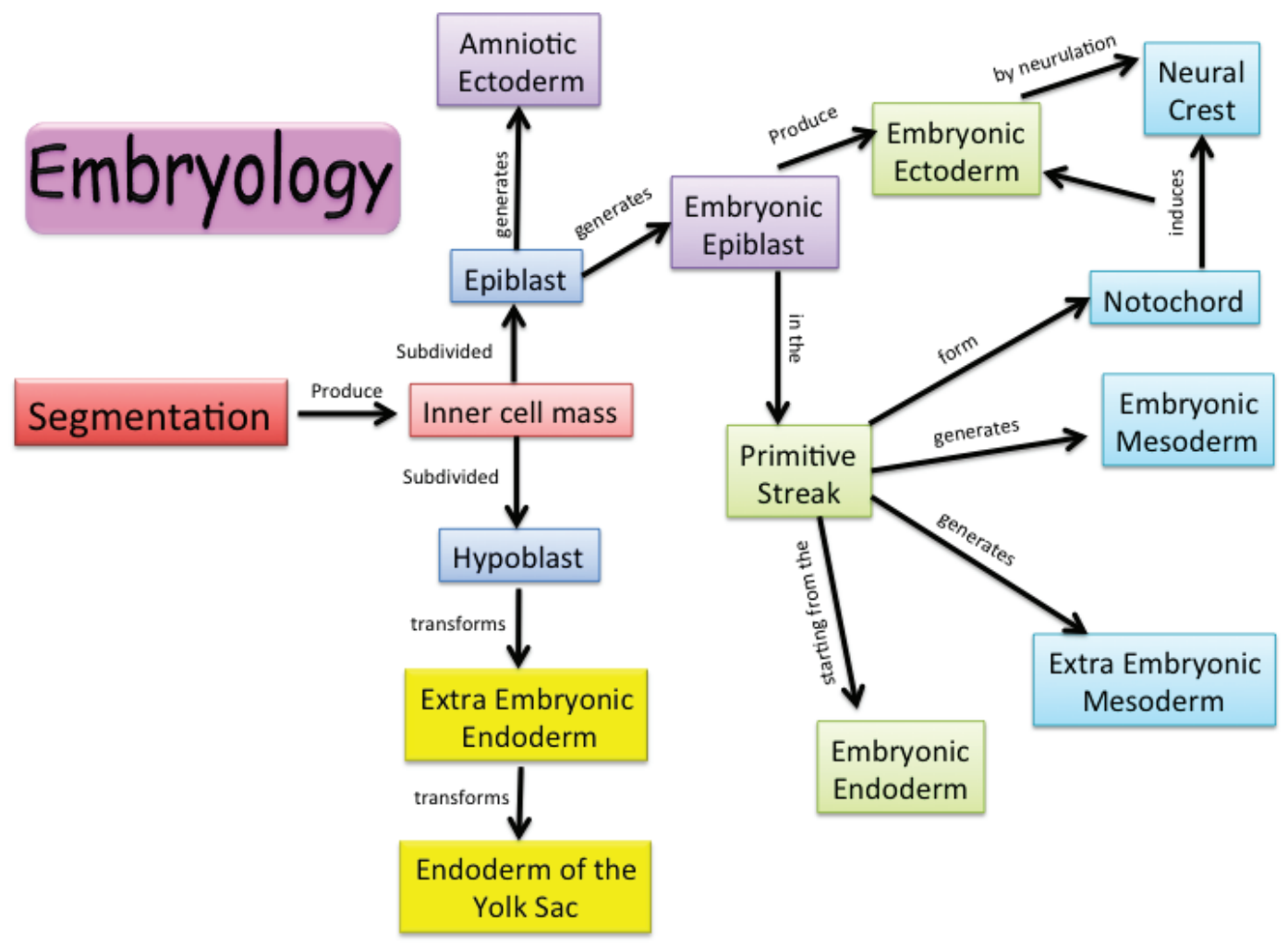

Figure 1. Embryology, Segmentation. 
We will now focus on the formation of the fascial network within the mesoderm or the middle layer. During the second week of embryological development, there is hardly any cellular differentiation; almost all cells are exact copies of each other. However, as the embryo develops, growing at an exponential rate, there is also further specialization which means that spatial reorganization becomes essential (Figure 2). At the center of the mesoderm there is a thickening called the notochord, which gives rise to the spinal column, vertebrate bodies and intervertebral discs. To the sides of the paraxial mesoderm there is a special section known as mesenchyme (literally 'tissue in the middle') (Snyder, 1975). Mesenchymal stem cells are progenitors of fibroblasts and other connective tissue cells. Mesenchymal stem cells migrate among cells to settle in the three linings and they secrete reticular fibers (a primitive form of collagen) into the interstitial space. These fibers are chemically connected, much like velcro, to form a network that covers all the body (Schultz \& Freitis, 1996). The mesenchymal stem cells are scattered throughout the body in order to differentiate themselves into other cell types where needed. They are a perfect example of the remarkable ability of connective tissue to adapt and respond to the continuous changes of the organism. Mesenchymal cells gradually replace the reticular fibers with the collagen fibers forming an only one fibrous net in the organism. That is the reason why favor the singular "fascia" over the plural "fasciae" (Myers, 2009). Once the three layers and the fascial cohesive network are established, it begins to fold onto and over itself repeatedly. The mesoderm covers the endoderm reaching to the ventral zone, where, from its in-between position, it gives rise to the ribs, the abdominal muscles and the pelvis. At the same time, it lodges and supports the endodermic digestive tract within (Cinnamon, 1999). The mesoderm moves to the dorsal zone where it forms the neural arch of the spinal cord as well as the cranial cavity that covers and protects the Central Nervous System (CNS) (Duprez, 2002). The palate is one of the last folds to connect together (when this process is not completed, a cleft lip results) (Moore \& Persaud, 1999). In the musculoskeletal system, the internal sac fixed to bone is referred to as the periosteum, but when it is a fibrous cuff surrounding an articulation it is known as an articular capsule. These connective tissue structures are always connected and they are continuous with one another throughout the body. The external sac forms, deforms, reforms and stabilizes different tensional lines in the intermuscular septum or investing fascia according to the growth and movement to which they are subjected. The tissue's tensional lines and the direction of the muscular fibers start from this process (Myers, 2009). The pattern of Tcf4 expression will determine how the muscles of the limbs within the mesoderm will be formed. From the beginning, the limbs will be organized according to these characteristics: from proximal to distal, from dorsal to ventral and from anterior to posterior. The signal that Tcf4-expressing cells give at a local level is through the secretion of inductive factors, or also through the deposition of an instructive extracellular matrix to induce myogenic precursors to distinguish into myotubes, which are in specific areas in the limb, serving as the nucleus for the anatomical formation of a future muscle. Following these primary signals, secondary signals join and are

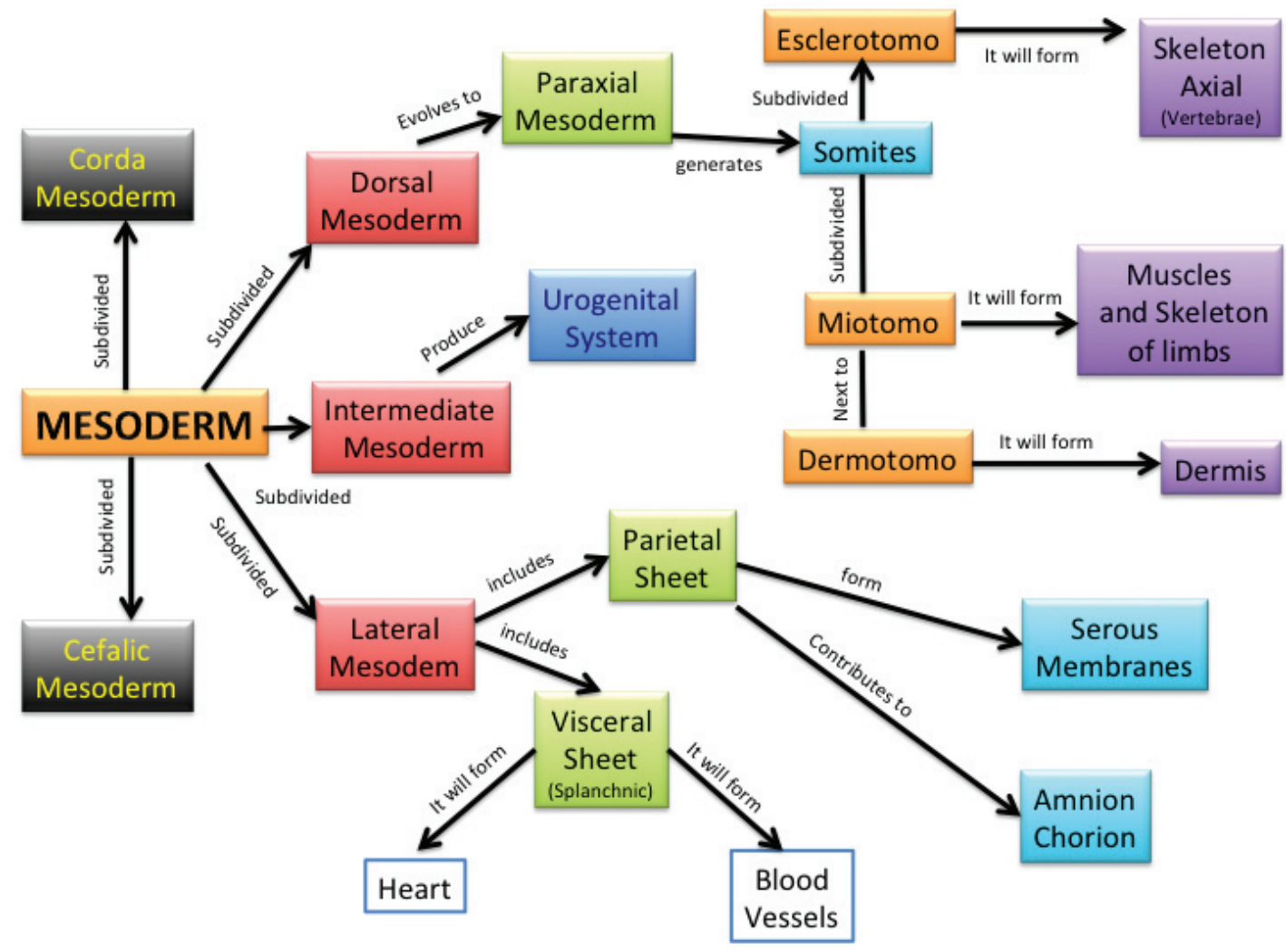

Figure 2. Mesoderm subdivision. 
integrated to produce an upregulation of Tcf4 in specific areas of the limb mesoderm (Blasi et al., 2015; Kardon et al., 2003). Connective tissue controls the patterns of muscle formation by guiding the migration of myoblasts through the mesoderm (Brand-Seberi \& Christ, 1999). Towards the end of the fifth week, future muscular cells are grouped together into two portions: a smaller epimere portion, organized in myotomes, and a larger hypomere portion in the ventral region. These portions subsequently form the epaxial and hypaxial muscles, respectively. Nerves that traverse segmental muscles, are also divided into a primary dorsal ramus for the epimere and a ventral ramus for the hypomere. They accompany the muscles throughout their migratory path (Figure 3). In particular:

- Voluntary muscles of the head: from the neural crest cells derive connective tissue elements that guide the patterns of muscle formation in the head; they derive from paraxial mesoderm (somitomeres and somites) and include the muscles of the tongue, the eye (some of them) and are associated with the pharyngeal arches (visceral) (Langman's Medical Embryology, 2001).

- Voluntary muscles of extremities: the mesenchyme is derived from dorsolateral cells of the somites, which move from each limb bud to form the muscles; this occurs near the seventh week of development and can be seen as a condensation (Chevallier et al., 1977; Cristo et al., 1977; Duprez, 2002; Zhi et al., 1996). From somatic mesoderm derives the connective tissue that makes the muscle pattern formation of the limb bones (Langman's Medical Embryology, 2001; Sadler, 2001).

Spinal nerves play an important role in the differentiation and motor innervation of the limb musculature, and they, as well, provide sensory innervation to dermatomes (Langman's Medical Embryology, 2001).

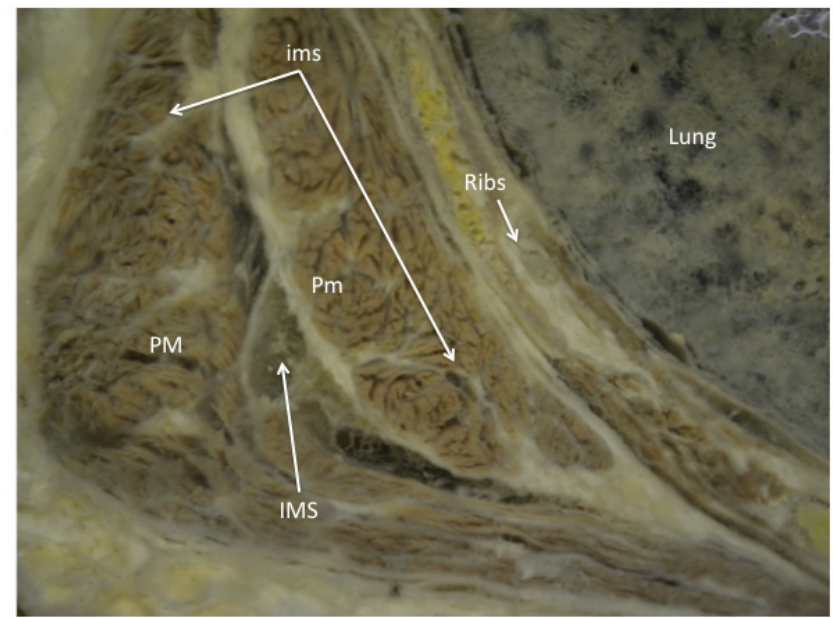

Figure 3. Axial view: the different intramuscular septa (ims) connecting the different muscular bundles (pockets) and intermuscular septa (IMS) that connect the muscular bundles of different muscles (pockets). Pectoralis Major PM; pectoralis minor pm; intramuscular septa ims; intermuscular septa IMS. Department of Anatomy at the University of Salvador, School of Medicine, Buenos Aires, Argentina.
Sobolevskii explains in his article that "Comparative anatomy of the spinal cord of the terrestrial, aquatic and semi-aquatic mammals of animals" to the nerve fascicle takes its origin from the spinal cord and elongation of nerve bands, going from the spinal cord to spinal ganglia.

\section{Anatomy and physiology}

Classically, more attention is given to the connections between the muscles and the skeleton via the tendons of origin and insertion. The recruitment of muscle fibers generates mechanical tension that, via these tendon connections, produces either musculoskeletal movement or maintenance of a static position, thus stabilizing the body (Turrina et al., 2012). Different authors (Hujing, 2003; Huijing \& Baan, 2001a; Huijing \& Baan, 2001b; Stecco, 2009a; Stecco, 2009b) describe myotendinous expansions that extend from the deep fascia, or extramuscular connective tissue, of muscles to attach to the deep fascia in adjacent segments, periarticular soft tissues, intermuscular septa, interosseous membranes and neurovascular sheaths (Platzer, 1978; Standring et al., 2005; Tidball \& col., 1991). Due to these connections, muscles acquire additional surfaces for leverage and the generation of movement (Huijing \& Jaspers, 2005; Stecco et al., 2010a; Stecco et al., 2010b; Yucesoy et al., 2010). Via these myotendinous expansions, which are a type of extension of the tendons, muscles can directly stretch deep fascia in a number of body segments in a longitudinal sense (Huijing, 2009; Stecco et al., 2007a). They can also stretch it transversally through intramuscular connective tissue (endomysium, perimysium and epimysium) (Huijing \& Jaspers, 2005; Monti et al., 1999; Purslow, 2010), as well as through other parts of the musculoskeletal connective tissue (such as the intermuscular septum and neurovascular bundles).

It is also well established that, during a muscular contraction, not all motor units within recruited muscles are activated simultaneously (Finni et al., 2003; Pappas et al., 2002). The presence of intramuscular connective tissue plays a fundamental role in the synchronization of the many variables involved in force production. (Rowe, 1981), as does the retinacula of deep fascia (Sanchis-Alfonso \& Rosello-Sastre, 2000).

Intramuscular connective tissue, from the macroscopic to the microscopic aspect, can be defined as:

Epimysium: thicker than the other elements of the intramuscular tissue, it is formed by large diameter collagen fibers (Sakamoto, 1996). In the extreme of the muscle the epimysium thickens before it merges with the tendons of origin and insertion (Benjamin, 2009) and converges in the paratenon, while the muscle belly, which it covers, forms a thin layer that determines the volume of the muscle. Wherever epimysium of two muscles connects, it forms a connective tissue sheath that envelops vessels and nerves destined to reach these muscles. Between the collagen fibers, there is the ground substance, which is rich in hyaluronic acid and other glycosaminoglycans (McCombe et al., 2001). In particular, the hyaluronic acid component allows collagen fibers to slide freely, allowing relative mobility of intrafascial layers (Stecco et al., 2011).

Perimysium: surrounding the muscle and the tendon of origin and insertion of the same muscle, this perimysium does not present 
a solution of continuity with the epimysium. The amount of perimysium within each muscle and each region of the body varies. The perimysium divides the muscle belly into fascicles of different sizes. Histologically, perimysium has a smaller percentage of elastic fibers and especially collagen fibers type I, III, IV, V, VI and XII, immersed in a matrix of proteoglycans (Kurose et al., 2006; Petibois et al., 2006). The collagen type I fibers provide the perimysium with great resistance to traction. It is probable that, in the transmission of force generated by the muscle towards bone levers, intramuscular connective tissue play an important role (Turrina et al., 2012). In addition, in between two adjacent muscle bundles is placed the same perimysium that contacts with both fascicles by its opposite surface.

Endomysium: is the thinner portion of intramuscular connective tissue. It is directly in contact with the sarcolemma and therefore with every single muscle fiber. Covering the muscular fiber in its entire surface, it takes on a structural role, similar to the parenchyma within organs (Moore, 1983). Endomysium creates a network that unites adjacent fibers. It is the only intramuscular element that, within each muscular fascicle, has contact with the individual muscular fibers innervated by the same motor unit. Other muscular fibers may be interposed but they may remain inactive during the activation of a given motor unit. Thanks to the endomysium, the muscle fibers that are not recruited represent a 'true tendon' for the transmission of force laterally, without having to change length (Trotter, 1990). To analyze the properties and structure of a muscle must take into account the arrangement of fibers in relation to the aponeurosis and tendons. (Finni et al., 2003; Turrina et al., 2012) Figure 4.

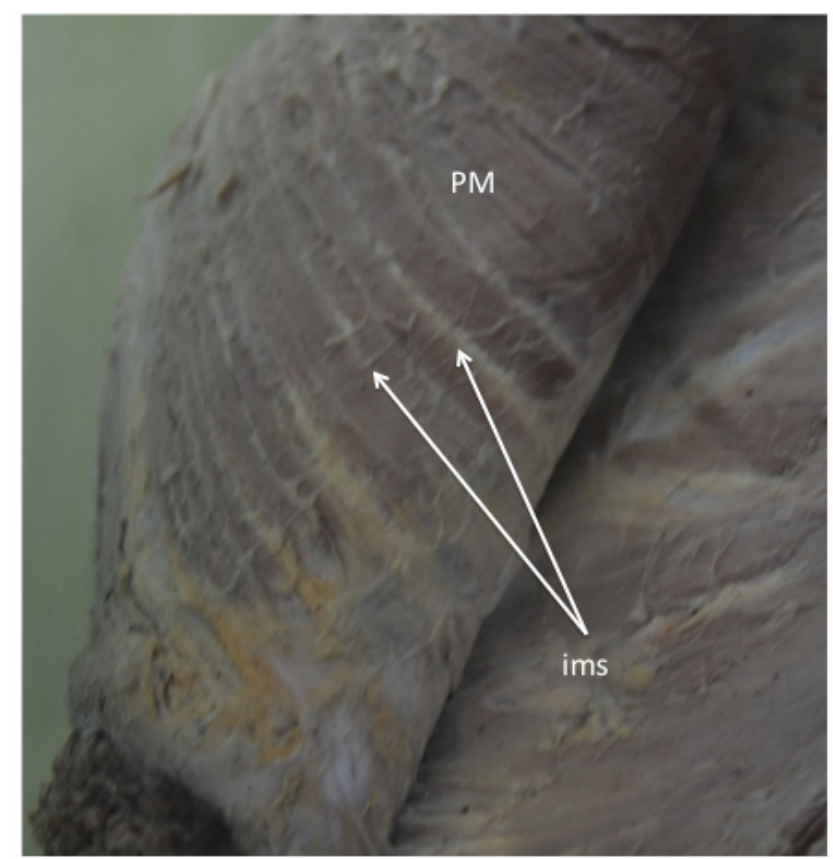

Figure 4. Intramuscular septa (ims) of Pectoral Major (PM) disinserted of sternal portion. Department of Anatomy at the University of Salvador, School of Medicine, Buenos Aires, Argentina.
It is evident that right from embryological development, the fascia determines the structural and functional characteristics of the muscle.

During evolution: the independence of the various segments meant that the myomeres and myosepta were required to align themselves according to new lines of force, thus abandoning metamerism altogether. Previously the entire musculature of a body intervened every time it was moved in any direction, or plane, but at this stage each part of the body required its own musculature (Chiarugi, 1975; Stecco, 2004). In this way, the method of Fascial Manipulation organized into six myofascial units, formed by mono and biarticular fibres as well as muscle spindles, were created for each segment.

The evolutionary process proceeded in the following manner:

- at first metameres lengthened according to the lines of tension;

- then the myosepta, or metameric septa, in part joined with the unidirectional muscle fibres to form the muscle spindles and, in part, surrounded the entire muscular mass to form the epimysium (Chiarugi, 1975; Stecco, 2004).

From the observation of this process in bony fishes we find that lateral flexion of the trunk stimulated the myomeres to elongate in a cephalo-caudal sense which in turn induced the myosepta-fasciae to align parallel to the traction. Hence, these fibres lengthened and they connected to a number of segments (Figure 5).

As a consequence, the myosepta-fasciae, which are no longer metameric, lengthened between the muscle fibres to form the perimysium. The deep muscles maintained parallel fibres between one vertebra and the next, somewhat similar to the first metameric stage. The more superficial muscles however formed links extend over a number of metameres. The multisegmentary muscular fibres have the muscle spindles, which are placed in parallel to them, as their point of reference. The muscle spindle is the connection between the unidirectional muscular fibres and the relative portion of the primordial fascia (Stecco, 2004). Only the presence of the muscle spindles, plus the activation of the muscular fibres in succession,

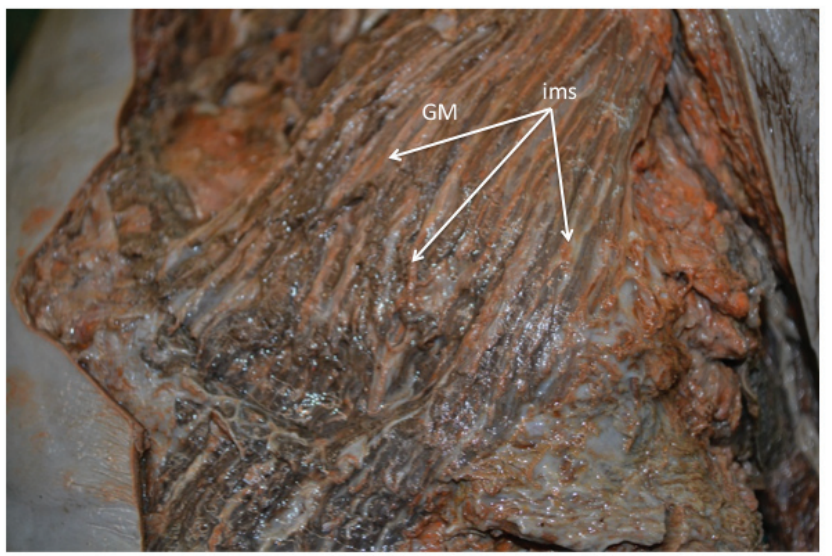

Figure 5. Intramuscular septa (ims) of Gluteus Maximus (GM). Department of Anatomy at the University of Salvador, School of Medicine, Buenos Aires, Argentina. 
allows for the arrest of movement at any angle of the entire joint range. Due to the muscle spindles and the Golgi tendon organs, the unidirectional fibres intervene in succession during the movement of a body part in one plane (Stecco, 2004). The evolution of peripheral receptors clearly demonstrates how the brain depends upon the fascia in order to be able to formulate the concept of space and time. To enable it to organise movement, in general the brain requires feedback concerning whatever is taking place in the periphery. Normally the free nerve endings are involved in deep somaesthetic activity or the perception of the body's position and movement in space. This feedback transmits information to the CNS regarding the exact position of any given body segment. The fascia and, in particular, its directional sequences, have a predefined length and therefore can act as a type of measuring device in the periphery. Furthermore, because of its elasticity, it is also capable of applying stretch to neuroreceptors (Kent, 1997); (Stecco, 2004). According to the angle of the articulation and therefore, the fascial stretch, either a sequence, a diagonal or a spiral is activated with each step or movement. In other words the mind initiates a motor scheme and the fascia assists in the process of its realisation (Stecco, 2004). The functional meaning of this relationship between the activity of the muscle, the mobility of intra and extramuscular connective tissue and, function of intermuscular septa to achieve the formation of sequences, diagonals, and the spirals of movement, should be studied by also taking into account the presence of numerous embedded receptors that may play a role in peripheral coordination of movement. (Stecco, 2004; Stecco, 2007a; Stiwell, 1957; Turrina et al., 2012; Yahia et al., 1992).

\section{Discussion}

\section{Organization of movement patterns}

In the 1940s, when Doctor Herman Kabat began to develop the concept of Proprioceptive Neuromuscular Facilitation (PNF) (Voss et al., 2001), it was sustained that normal neuromuscular mechanisms were capable of developing a wide range of motor activities within the limits of the anatomical structure, the level of development, and innate and previously learnt neuromuscular responses. In other words, the countless combinations of movement that an individual employs to satisfy everyday needs are acquired by means of a well-established process of development and an abundance of learning situations. Neuromuscular mechanisms are assimilated and become efficient without paying attention to individual muscular activity, reflex activity, or the enormous amount of neurophysiologic reactions involved. In the introduction to the PNF method (Voss et al., 2001) it is stated that 'movement patterns are mass movement patterns. Mass movement is a characteristic of normal motor activity and it is in consonance with Beevor's Axiom: the brain knows nothing of individual muscle action, but knows only of movement. In normal motor activity, the varied combinations of movement, or mass movement, demand shortening and lengthening reactions from many muscles and in different degrees. Mass movement, which has the purpose of setting out a specific demand, has to consist of a special combination of movements, ideal to the specific sequence of muscles responsible for that movement and has to allow those muscles to contribute with their action components in a harmonic way'.
More recently, (Myers, 2009) has suggested that perhaps there are not in fact 600 muscles but a single connective tissues system with "pockets, which gives muscles and muscles fibers to settle their spaces in different directions to perform its function.

In neurophysiology, we find that movement is programmed by the mind and carried out by the contraction of the muscle fibers. Nerve impulses generated from the brain determine the displacement of a certain segment and it is subject to a vast number of variables in the periphery (Stecco \& Stecco, 2010).

Given that each muscle has fibers with different functions and innervations (Burke et al., 1974), according to the Fascial Manipulation ${ }^{\circledR}$ concept (Stecco, 2004), the musculoskeletal system could be divided into myofascial units (MFUs). Each MFU is said to be composed of motor units responsible for moving a segment in a specific direction and, along with the fascia surrounding these fibers, these forces generate movement vectors. A MFU necessarily includes the nerve components innervating these elements. Furthermore, the main vectors of each MFU generate other smaller, more distant vectors (Stecco, 2013).

The fascial context in which muscle fibers are inserted could potentially coordinate movement in the periphery. The MFU is the element that could synchronize the action of motor units innervated by the same axon. While the brain sends impulses to muscle fibers scattered within the muscle via the axon of a single motor neuron, diminishing the activity of the more distal fibers and increasing it in the most proximal ones in relation to changing positions of the limb or the required force presents neurological challenges. An elastic structure, sensitive to stretch, such as the fascia, could assist modulation of recruitment or inhibition via the activation of mechanoreceptors embedded in this tissue (Stecco \& Stecco, 2004) The potential role of these mechanoreceptors in the coordination and synchronization of movement via their proprioceptive function is emphasized. As connective tissue continues in the tendons and the muscle insertions (Hujing, 2003; Huijing \& Baan, 2001a; Huijing \& Baan, 2001b; Stecco, 2009a; Stecco, 2009b), it also distributes and directs the muscular force to the bone in an appropriate way (Stecco \& Stecco, 2010).

\section{New questions for research}

1) If the brain is not aware of individual muscle activity, but knows and plans movement in terms of patterns (Beever's axiom), should we continue thinking in terms of individual muscles bringing about movement?

2) Is there a central command that sends an order through nerve impulses, all or nothing, and are there peripheral systems that regulate coordination and synchronization according to the requirements of movement patterns? Is the brain really in charge of everything?

3) If the brain coordinates, regulates and synchronizes everything, what is the purpose of the peripheral nervous system, the fascia and its embedded mechanoreceptors? 
From this review, a new comprehension of the connective tissue in general, and more specifically, of the musculoskeletal system emerges:

- The connective tissue drives musculoskeletal development from conception.

- In the 1940 s, prompted by his rehabilitative work with patients affected by poliomyelitis, Kabat initiated discussion concerning how the brain interprets movement in terms of finalized gestures or patterns of movement.

- In the 70s, Stecco developed a comprehensive method (Fascial Manipulation ${ }^{\circledR}$ ) based on similar reasoning, introducing the potential role of muscular fascia in musculoskeletal activity.

- $\quad$ More recent studies concerning the anatomy and physiology of intramuscular and extramuscular connective tissue and its innervation suggest that the myo-fascial-skeletal system presents peripheral response mechanisms that are capable of responding to movement patterns.

- These mechanisms include functions such as musculoskeletal coordination, synchronization, regulation of movement, and the transmission of contractile force from the muscle fibers and fascicles within muscles and as well as along body segments via myotendinous expansions and intramuscular septa. Lastly, the neurovascular tracts, wrapped in fascia, also transmit contractile force (Karassolik et al., 2009; Lindsay, 2008). As suggested by Langevin (2006), the fascial system represents a 'body-wide proprioceptive/communicating organ'.

\section{Conclusion}

Connective tissue guides our developmental phases during intrauterine life and continues to evolve through movement patterns. In addition, the brain apparently knows very little about individual muscle action, but recognizes movement patterns catalogued by learning. Muscle fibers and fascicles are oriented in a direction dictated by their connective tissue in a pre-established pattern, reinforced through movement patterns and modified to adjust to the individual, making it effectively redundant to name every muscle involved in the process. With ongoing research concerning the anatomy and physiology of the myo-fascial-skeletal system is it not time for a paradigm shift with regards to this system?

\section{Author contributions}

Author, Carolina Marchuk PT DO: in late 2014 began to read about the article and began to cross data of different authors, some old and many contemporaries, grew to investigate this idea of thinking different from musculoskeletal origin (Embryology) to its development functional (Anatomy and Physiology), as well as it was developed during our evolution, it was important to investigate the roles that the brain and mechanoreceptors, so it was that wrote and edited this review with the great contribution and ongoing monitoring of the co-author Carla Stecco, MD.

When I read various articles or books I always ask: "Why?" and so I questioned to know and understand a little more about our locomotor function and disfunction.

Co - Author, Prof. Carla Stecco MD: is Assistant Professor of Department of Molecular Medicine and one of the most Recognize Anatomist in the field of Fascia. She is Assistant professor of Department of Molecular Medicine to Padova University and is known worldwide for her studies in the connective tissue and she is the author and co-author of several books on fascias as well as the method created by her father (Luigi Stecco) Fascial Manipulation Method.

Carla Stecco contributed to monitoring, ongoing review of the wording and great knowledge of the subject of this article as well as a significant contribution of bibliographic material.

\section{Competing interests}

No competing interests were disclosed.

\section{Grant information}

The author(s) declared that no grants were involved in supporting this work.

\section{Acknowledgements}

- Julie Ann Day PT, Fascial Manipulation ${ }^{\circledR}$ Teacher, for their suggestions and correction in the wording.

- Cheryl Megalos PT and Fascial Manipulation ${ }^{\odot}$ Teacher, for collaboration in the translation of this article.

- Patricia Candia PT: Anatomy Teacher of the Degree in Physical Therapy from the University of Salvador, she belongs to the staff of the Department of Anatomy, School of Medicine, Universidad del Salvador, Buenos Aires Argentina.
Benjamin M: The fascia of the limbs and back--a review. J Anat. 2009; 214(1):

$1-18$.

PubMed Abstract | Publisher Full Text | Free Full Text

Blasi M, Blasi J, Domingo T, et al: Anatomical and histological study of human

deep fasciae development. Surg Radiol Anat. 2015; 37(6): 571-8.

PubMed Abstract | Publisher Full Text

Brand-Seberi B, Christ B: Genetic and epigenetic control of muscle

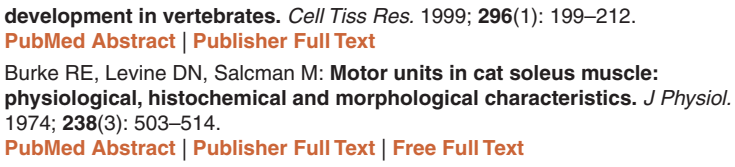

development in vertebrates. Cell Tiss Res. 1999; 296(1): 199-212. PubMed Abstract | Publisher Full Text

Burke RE, Levine DN, Salcman M: Motor units in cat soleus muscle: physiological, histochemical and morphological characteristics. J Physiol. 1974; 238(3): 503-514.

PubMed Abstract | Publisher Full Text | Free Full Text

Cinnamon Y, Kahane N, Kalcheim C: Characterization of the early development 
of specific hypaxial muscles from the ventrolateral myotome. Development. 1999; 126(19): 4305-4315.

PubMed Abstract

Chevallier A, Kieny M, Mauger A: Limb-somite relationship: origin of the limb musculature. J Embryol Exp Morphol. 1977; 41: 245-58.

PubMed Abstract

Chiarugi G, Bucciante L: Instituzioni di Anatomia dell'uomo. Ed. Vallardi-Piccin:

Padova, Italy. 1975

Reference Source

Christ B, Jacob HJ, Jacob M: Experimental analysis of the origin of the wing musculature in avian embryos. Anat Embryol (Berl). 1977; 150(2): 171-86. PubMed Abstract | Publisher Full Tex

Duprez D: Signals regulating muscle formation in the limb during embryonic development. Int J Dev Biol. 2002; 46(7): 915-925.

PubMed Abstract

Finni T, Hodgson JA, Lai AM, et al.: Mapping of movement in the isometrically contracting human soleus muscle reveals details of its structural and functional complexity. J Appl Physiol (1985). 2003; 95(5): 2128-2133.

PubMed Abstract | Publisher Full Text

Huijing PA, Baan GC: Extramuscular myofascial force transmission within the rat anterior tibial compartment: proximo-distal differences in muscle force. Acta Physiol Scand. 2001a; 173(3): 297-311.

PubMed Abstract | Publisher Full Text

Huijing PA, Baan GC: Myofascial force transmission causes interaction between adjacent muscles and connective tissue: effects of blunt dissection and compartmental fasciotomy on length force characteristics of rat extenso digitorum longus muscle. Arch Physiol Biochem. 2001b; 109(2): 97-109.

PubMed Abstract | Publisher Full Tex

Huijing PA, Maas H, Baan GC: Compartmental fasciotomy and isolating a muscle from neighboring muscles interfere with myofascial force transmission within the rat anterior crural compartment. J Morphol. 2003; 256(3): 306-321. PubMed Abstract | Publisher Full Text

Huijing PA, Jaspers RT: Adaptation of muscle size and myofascial force transmission: a review and some new experimental results. Scand J Med Sci Sports. 2005; 15(6): 349-380.

PubMed Abstract | Publisher Full Text

Huijing PA: Epimuscular myofascial force transmission: a historical review and implications for new research. International Society of Biomechanics Muybridge Award Lecture, Taipei, 2007. J Biomech. 2009; 42(1): 9-21. PubMed Abstract | Publisher Full Text

Kardon G, Harfe BD, Tabin CJ: A Tcf4-Positive Mesodermal Population Provides a Prepattern for Vertebrate Limb Muscle Patterning. Dev Cell. 2003; 5(6): 937-944.

PubMed Abstract | Publisher Full Tex

Kassolik K, Jaskólska A, Kisiel-Sajewicz K, et al.: Tensegrity principle in massage demonstrated by electro- and mechanomyography. J Bodyw Mov Ther. 2009; 13(2): $164-170$.

PubMed Abstract | Publisher Full Tex

Kent CG: Anatomia comparata dei vertebrali. Ed Piccin, Padova, Italy. 1997. Reference Source

Kurose $\mathrm{T}$, Asai $\mathrm{Y}$, Mori E, et al.: Distribution and change of collagen types I and III and elastin in developing leg muscle in rat. Hiroshima J Med Sci. 2006; 55(3): 85-91.

PubMed Abstract

Langevin HM: Connective tissue: a body-wide signaling network? Med

Hypotheses. 2006a; 66(6): 1074-1077.

PubMed Abstract | Publisher Full Text

Langevin HM, Bouffard NA, Badger GJ, et al: Subcutaneous tissue

fibroblast cytoskeletal remodeling induced by acupuncture: evidence for a mechanotransduction-based mechanism. J Cell Physiol. 2006b; 207(3): 767-774.

PubMed Abstract | Publisher Full Text

Langman's Medical Embryology. 8th edition in Spanish. Ed. Lippincott Williams \& Wilkins. 2001. ISBN 950-06-1367-0 / 84-7903-655-9.

Lindsay M: Fascia: clinical applications for health and human performance. Delmar Cengage Learning. New York. 2008.

Reference Source

McCombe D, Brown T, Slavin J, et al.: The histochemical structure of the deep fascia and its structural response to surgery. J Hand Surg Br. 2001; 26(2): 89-97.

PubMed Abstract | Publisher Full Text

Myers TW: Vías Anatómicas. 2nd ed. Barcelona, España: Elsevier Masson. 2009 36-44.

Reference Source

Monti RJ, Roy RR, Hodgson JA, et al: Transmission of forces within mammalian skeletal muscles. J Biomech. 1999; 32(4): 371-380.

PubMed Abstract | Publisher Full Text

Moore K, Persaud T: The developing human. 6th edn. London: WB Saunders. 1999: 23-221.

Moore MJ: The dual connective tissue system of rat soleus muscle. Muscle Nerve. 1983; 6(6): 416-422.

PubMed Abstract | Publisher Full Text

Pappas GP, Asakawa DS, Delp SL, et al.: Nonuniform shortening in the biceps brachii during elbow flexion. J Appl Physiol (1985). 2002; 92(6): 2381-2389 PubMed Abstract | Publisher Full Text

Petibois C, Gouspillou G, Wehbe K, et al: Analysis of type I and IV collagens by FT-IR spectroscopy and imaging for a molecular investigation of skeletal muscle connective tissue. Anal Bioanal Chem. 2006; 386(7-8): 1961-1966. PubMed Abstract | Publisher Full Text

Platzer W: Locomotor system. In: Kahle W, Leonhardt H, Platzer W, (Eds.), Color Atlas and Textbook of Human Anatomy. First ed, Georg Thieme Publishers, Stuttgart. 1978.

Purslow PP: Muscle fascia and force transmission. J Bodyw Mov Ther. 2010; 4(4): 411-417.

PubMed Abstract | Publisher Full Text

Rowe RW: Morphology of perimysial and endomysial connective tissue in skeletal muscle. Tissue Cell. 1981; 13(4): 681-690.

PubMed Abstract | Publisher Full Text

Sadler TW: Langman Embriología Médica. 8va ed. Buenos Aires, Argentina: Editorial Médica Panamericana. Ed. Lippincot Williams \& Wilkins. 2001; 181-185. Reference Source

Sanchis-Alfonso V, Roselló-Sastre E: Immunohistochemical analysis for neural markers of the lateral retinaculum in patients with isolated symptomatic patellofemoral malalignment. A neuroanatomic basis for anterior knee pain in the active young patient. Am J Sports Med. 2000; 28(5): 725-731.

PubMed Abstract

Sakamoto Y: Histological features of endomysium, perimysium and epimysium in rat lateral pterygoid muscle. J Morphol. 1996; 227(1): 113-119.

PubMed Abstract | Publisher Full Text

Schultz L, Freitis R: The endless web. Berkeley, North Atlantic Books. 1996; 8-10. Snyder G: Fasciae: applied anatomy and physiology. Kirksville College of Ostheopaty, 1975.

Standring S, Ellis H, Healy J, et al.: Gray's Anatomy. 39th ed. Churchill Livingstone, London. 2005.

Stecco L: Fascial Manipulation for Musculoskeletal Pain. Ed Piccin Nuova

Libraria S.p.A., Padova, Italy, ISBN 88-299-1697-8. 2004.

Reference Source

Stecco C, Gagey O, Macchi V, et al:: Tendinous muscular insertions onto the deep fascia of the upper limb. First part: anatomical study . Morphologie. 2007a; 91(292): 29-37.

PubMed Abstract | Publisher Full Text

Stecco C, Porzionato A, Macchi V, et al.: The expansions of the pectoral girdle muscles onto the brachial fascia: morphological aspects and spatial disposition. Cells Tissues Organs. 2008. 188(3): 320-9.

PubMed Abstract | Publisher Full Text

Stecco A, Macchi V, Stecco C, et al.: Anatomical study of myofascial continuity in the anterior region of the upper limb. J Bodyw Mov Ther. 2009a; 13(1): 53-62. PubMed Abstract | Publisher Full Tex

Stecco A, Macchi V, Masiero S, et al:: Pectoral and femoral fasciae: common aspects and regional specializations. Surg Radiol Anat. 2009b; 31(1): 35-42. PubMed Abstract | Publisher Full Text

Stecco L, Stecco A: Manipulación Fascial (parte teórica). En español. 2da. ed. Caracas, Venezuela: Amolca. 2013; 9-35.

Reference Source

Stecco C, Stern R, Porzionato A, et al.: Hyaluronan within fascia in the etiology of myofascial pain. Surg Radiol Anat. 2011; 33(10): 891-896.

PubMed Abstract | Publisher Full Text

Stilwell D: Regional variations in the innervation of deep fasciae and aponeuroses. Anat Rec. 1954; 23 : 94-104.

Tidball JG, Law DJ: Dystrophin is required for normal thin filament-membrane associations at myotendinous junctions. Am J Pathol. 1991; 138(1): 17-21. PubMed Abstract | Free Full Text

Trotter JA: Interfiber tension transmission in series-fibered muscles of the cat hindlimb. J Morphol. 1990; 206(3): 351-361.

PubMed Abstract | Publisher Full Tex

Turrina A, Martínez-González MA, Stecco C: The muscular force transmission system: Role of the intramuscular connective tissue. J Bodyw Mov Ther 2013; 17(1): 95-102.

PubMed Abstract | Publisher Full Tex

Voss DE, Ionta MK, Myers BJ: Facilitación Neuromuscular Propioceptiva,

patrones y técnicas. 3ra ed. Buenos Aires, Argentina: Editorial Médica

Panamericana. 2001; 19-29.

Reference Source

Yahia H, Rhalmi S, Newman N, et al:: Sensory innervation of human thoracolumbar fascia. An immunohistochemical study. Acta Orthop Scand. 1992; 63(2): 195-197.

PubMed Abstract | Publisher Full Text

Yucesoy CA, Baan G, Huijing PA: Epimuscular myofascial force transmission occurs in the rat between the deep flexor muscles and their antagonistic

muscles. J Electromyogr Kinesiol. 2010; 20(1): 118-126.

PubMed Abstract | Publisher Full Text

Zhi $Q$, Huang $R$, Christ $B$, et al:: Participation of individual brachial somites in skeletal muscles of the avian distal wing. Anat Embryol (Berl). 1996; 194(4):

327-39.

PubMed Abstract | Publisher Full Text 


\section{Open Peer Review}

\section{Current Peer Review Status: ? ?}

\section{Version 1}

Reviewer Report 12 August 2016

https://doi.org/10.5256/f1000research.7337.r15642

(C) 2016 Hughes S. This is an open access peer review report distributed under the terms of the Creative Commons Attribution License, which permits unrestricted use, distribution, and reproduction in any medium, provided the original work is properly cited.

\section{Simon Hughes}

Randall Division of Cell and Molecular Biophysics, King's College London, London, SE1 1UL, UK

I find this article both old-fashioned/out-dated in parts and filled with platitudes or assertions not substantiated by clear references. While some relevant literature is mentioned, the text fails to provide a coherent and balanced account for the naive reader attempting to understand the field.

For example, embryonic ages mentioned appear to refer to human development (although this is not stated), yet assertions concerning the role of TCF4, for example, are included in these paragraphs. As far as I am aware most work on Tcf4 function has been done in chick, mouse or other model organisms (including that quoted by Kardon and colleagues). Essentially no data is available showing a functional role of TCF4 in human muscle connective tissue development. Instead, according to OMIM, TCF4 mutations contribute to neural and epithelial phenotypes in Pitt-Hopkins Syndrome and Fuchs Endothelial Corneal Dystrophy. Thus, while muscle involvement is a reasonable hypothesis based on conservation in evolution, and while genetic variations in people may in future reveal a role, to my knowledge no clear link is as yet apparent. A useful and informative review would make these issues explicit.

There are sentences in this work, such as 'In this way, the method of Fascial Manipulation organized into six myofascial units, formed by mono and biarticular fibres as well as muscle spindles, were created for each segment.', that are incomprehensible. For a start, this sentence is ungrammatical. But more seriously, it is meaningless. If Fascial Manipulation is a 'method', how can such a method be 'organized into six myofascial units'? The latter sound like anatomical structures in this sentence. At best, this is a very poorly thought-out sentence. At worst, it is an example of attempting to justify a medical treatment using obscurantist scientific jargon with no clear underlying meaning: blinding the naive with 'science'.

Another example is the use a a picture in Fig 5 of what may be human gluteus maximus muscle to demonstrate an unclear point about 'bony fishes' and to conclude 'Hence, these fibres lengthened and they connected to a number of segments'. As far as I can tell there are no segments in the anatomical sense in the gluteus maximus. The idea/view being suggested here is totally unclear. 
Such non sequiturs are scattered throughout the manuscript.

Beevor may have said 'the brain knows nothing of individual muscle action' in 1940, but in 2015/6 this is no longer a tenable view. It is quite clear that individual muscle spindles provide feedback to the CNS concerning individual muscle movement and tension and there is no reason to suppose that such information could not be transmitted to the brain. The mentioning of Fascial Manipulation and PNF without clear explanation is a huge omission. One is tempted to ask whether the publication of this manuscript is more about acquiring a recently dated 'paper' to quote in other literature than to really illuminate a biomedically important issue? Certainly, I find the statements on new paradigms and the broad philosophical brain/body statements (including the 'New Questions' the least valuable parts of this manuscript as they are either not well explained or have already been answered. For example, the answers to the two questions in New Question 2 are an unequivocal 'yes' and 'yes'. For Question 3 there is an abundance of answers already in the literature: the motor axons of the PNS, for example, carry the information from CNS to muscle in terms of patterened series of action potentials.

I concur with Ben Feldman, with the exception that I would be more severe on the author's use of the term 'mesenchyme'. In my understanding of modern cell biology, mesenchyme is used to describe a tissue that is not epithelial and has no specific relationship to particular regions of the body or developmental origin of the tissue. Thus mesenchymes in different tissue can be derived from any germ layer and simply reflect a apparent lack of apical/basal polarity in the cells so described.

Competing Interests: No competing interests were disclosed.

\section{I confirm that I have read this submission and believe that I have an appropriate level of expertise to confirm that it is of an acceptable scientific standard, however I have significant reservations, as outlined above.}

Reviewer Report 22 July 2016

https://doi.org/10.5256/f1000research.7337.r15179

(C) 2016 Feldman B. This is an open access peer review report distributed under the terms of the Creative Commons Attribution License, which permits unrestricted use, distribution, and reproduction in any medium, provided the original work is properly cited.

\section{Benjamin Feldman}

Vertebrate Embryology Section, National Human Genome Research Institute (NHGRI), National Institutes of Health, Bethesda, MD, USA

This review sets out to challenge current thinking on the role of connective tissue. This is at its clearest in the "New questions for research" section where several concepts are listed that might guide new research or the interpretation of older research. Unfortunately the preceding text does not delineate with sufficient clarity or precision the context of potentially antiquated concepts or emerging ideas that would make these questions for new research seem important or relevant to 
the reader. Indeed, the promise in the title that this article will address a "paradigm shift" is simply not matched by a clear explanation of what old paradigm(s) are being questioned or what new paradigm(s) are being proposed. An explicit and specific synopsis of what concepts are being challenged and proposed is urgently needed and should appear prominently in the Abstract and/or Introduction and should perhaps be reiterated in the Discussion and/or Conclusion.

More explicit and conventional organization would benefit the article in other ways. While there is a titled section on "Anatomy and physiology", the preceding text devoted to embryology falls in the titled "Introduction" section. This lack of symmetry and the immediate launch into embryological detail under the "Introduction" heading is confusing. Then there is a "Discussion" section in which the literature review continues, rather than switching to an overview or synthesis of what was presented in earlier sections, as normally occurs in a Discussion section. This inconsistent and non-conventional use of titled sections detracts from the article's sense of focus and direction.

Finally, there are a couple of needed improvements in the discussion of early development. 1) There are several Spanish words retained in Figure 2 where the following changes are needed: Corda to Chorda; Cefalic to Cephalic; Esclerotomo to Sclerotome; Miotomo to Myotome; Dermotomo to Dermatome. 2) The text discusses mesenchyme as a "special section" on the "sides of the paraxial mesoderm." But the term "mesenchyme" does not appear in Figure 2. I think it would be more correct and more in line with Figure 2, to say that the mesenchyme (with the exception of head mesenchyme) is derived from or formed from lateral plate mesoderm (or "a special section flanking the paraxial mesoderm") rather than defining it is an initial subdivision of the mesoderm.

Competing Interests: No competing interests were disclosed.

I confirm that I have read this submission and believe that I have an appropriate level of expertise to confirm that it is of an acceptable scientific standard, however I have significant reservations, as outlined above. 
The benefits of publishing with F1000Research:

- Your article is published within days, with no editorial bias

- You can publish traditional articles, null/negative results, case reports, data notes and more

- The peer review process is transparent and collaborative

- Your article is indexed in PubMed after passing peer review

- Dedicated customer support at every stage

For pre-submission enquiries, contact research@f1000.com 